\title{
Comparison of crude and adjusted mortality rates from leading causes of death in northeastern Brazil
}

\author{
Elisabeth França, ${ }^{1}$ Chalapati Rao, ${ }^{2}$ Daisy Maria Xavier de Abreu, ${ }^{1}$ \\ Maria de Fátima Marinho de Souza, ${ }^{3}$ and Alan D. Lopez ${ }^{2}$
}

Suggested citation França E, Rao C, Abreu DMX, Souza MFM, Lopez AD. Comparison of crude and adjusted mortality rates from leading causes of death in northeastern Brazil. Rev Panam Salud Publica. 2012;31(4): 275-82.

ABSTRACT Objective. To present how the adjustment of incompleteness and misclassification of causes of death in the vital registration (VR) system can contribute to more accurate estimates of the risk of mortality from leading causes of death in northeastern Brazil.

Methods. After estimating the total numbers of deaths by age and sex in Brazil's Northeast region in 2002-2004 by correcting for undercount in the VR data, adjustment algorithms were applied to the reported cause-of-death structure. Average anual age-standardized mortality rates were computed by cause, with and without the corrections, and compared to death rates for Brazil's South region after adjustments for potential misdiagnosis.

Results. Death rates from ischemic heart disease, lower respiratory infections, chronic obstructive pulmonary disease, and perinatal conditions were more than $100 \%$ higher for both sexes than what was suggested by the routine VR data. Corrected cause-specific mortality rates were higher in the Northeast region versus the South region for the majority of causes of death, including several noncommunicable conditions.

Conclusions. Failure to adjust VR data for undercount of cases reported and misdiagnoses will cause underestimation of mortality risks for the populations of the Northeast region, which are more vulnerable than those in other regions of the country. In order to more reliably understand the pattern of disease, all cause-specific mortality rates in poor populations should be adjusted.

Key words Cause of death; mortality; vital statistics; Brazil.

Accurate information on causes of death is fundamental for assessing population health status and determining program priorities. Birth and death statis-

\footnotetext{
Grupo de Pesquisas em Epidemiologia e Avaliação em Saúde, Universidade Federal de Minas Gerais, Belo Horizonte, Minas Gerais, Brazil. Send correspondence to: Elisabeth França, efranca@medicina.ufmg.br

2 School of Population Health, University of Queensland, Brisbane, Australia.

3 Area of Health Surveillance and Disease Prevention and Control, Pan American Health Organization, Washington, DC, United States of America.
}

tics derived from vital registration (VR) systems are the most important source of data for meeting policy needs. VR data provide details on the underlying cause of death, date of death, and other selected characteristics of the deceased. Unfortunately, few countries have good-quality data on mortality (1), and those that do tend to be the more developed ones (2).

Although imperfect, estimates of heath indicators are essential for improving overall public health (3). Such estimates are particularly crucial for some coun- tries in Latin America where the quality of national mortality data is a major concern. The Pan American Health Organization (PAHO) has reported that under-registration of deaths in the region varies from $0 \%$ to $42 \%$ (4). Furthermore, national cause-of-death statistics for countries with imperfect data are likely to be misleading because they may conceal important differentials between population subgroups (5).

Brazil, which has the fifth-largest population in the world, is divided into five 
administrative regions based on geography and economic activity. Despite recent economic and social development at the national level, there is considerable regional variation when income and social inequalities are taken into consideration (6). The Northeast region, which is home to 53 million Brazilians or $28 \%$ of the population, is weakly industrialized and thus remains underdeveloped, with the lowest human development index (HDI) among Brazil's five regions (7). The South region is the wealthiest and has the highest standard of living in the country. Hence, Brazil essentially comprises two different "countries": the Southern regions, which are dynamic and powerful, and the Northern regions, which are poor and less developed (8).

Due to the heterogeneous quality of the VR data across Brazil, substantial methodological problems arise when comparing patterns among causes of death at the subnational level $(9,10)$. Although several studies have noted problems with data quality in the analysis of mortality risks in various regions of Brazil (11-14), only a few have adjusted mortality rates for the potential bias introduced by undercounting and misdiagnoses, and those that did only reported mortality risks from specific causes of death $(15,16)$.

This study is a follow-up to research published in 2008 that analyzed the quality of Brazil's mortality data for 20022004, and the methods used for their measurement (10). Using the same time period in the current study allowed for the use of knowledge about potential biases described in the 2008 study, avoiding the need to present and explain the factors used to adjust the data. These follow-up data provide a baseline for studying trends in future mortality differentials and underscore the importance of credible cause-of-death analysis for underdeveloped regions. The purpose of the study was to present how the adjustment of incompleteness and misclassification of causes of death in VR information systems can contribute to more accurate estimates of the risks of mortality from leading causes of death in Brazil's Northeast region.

\section{MATERIALS AND METHODS}

A cross-sectional analysis of registered causes of death in Brazil's Northeast region for the period 2002-2004 was carried out. To correct observed biases in the data, several adjustment methods were applied, the details of which are described below. In brief, the data were first adjusted for undercount of death registration, which yielded an estimate of the true total number of deaths by age and sex in the region. Next, deaths with missing sex and/or age were proportionately distributed pro rata across the defined categories. Subsequently, the reported cause-of-death structure was adjusted for the discrepancies arising from improper death certification and coding that had resulted in deaths being allocated to ill-defined causes or categories of limited public health utility. The adjusted proportionate cause structure was fitted to the estimated total deaths to derive mortality estimates by age, sex, and cause.

\section{Estimating total mortality}

Estimates of the total number of deaths by age and sex were based on the results of the sex-specific life tables for the Northeast region described elsewhere (10). In brief, this life table was constructed using the National Household Sample Survey (NHSS) estimate of child mortality from 2003 and an adjusted estimate of adult mortality (derived by applying the extinct generation method (EGM) to estimate undercount) as inputs into the modified-logit life table system (17). As the EGM method assumes that death undercount is constant across all adult ages, the uniform EGM estimate of completeness of death registration for all ages above 5 years was further adjusted by accounting for variations in completeness in different age groups based on recent evidence (18). Correction factors of estimated mortality undercount for each age group and sex were then applied to the observed mortality data to estimate the mortality "envelope" (total number of estimated deaths) by age and sex.

\section{Correcting causes of death}

To correct potential miscoding of the causes of death, registered deaths of people residing in the Northeast region of Brazil between 2002 and 2004 were averaged to derive an annual number of registered deaths by age, sex, and cause during that period. Next, the detailed
ICD- $10^{4}$ codes for cause of death were retabulated according to the list summary used in the World Health Organization (WHO) global burden of disease (GBD) study (19). Correction algorithms were then applied for the various causes of death as described below:

- Maternal deaths: An estimate of all maternal deaths in 2002-2004 was derived by applying a correction factor of 1.4 to the number of maternal deaths recorded in the VR data, based on previous research (20).

- Cardiac diseases: Nonspecific codes I46, I47.2, I49.0, I50, I51.4, I51.5, I51.6, I51.9, and I70.9 were redistributed according to the specific algorithm of the GBD method (21).

- Cancer: Nonspecific cancer codes C76, C80, and C97 were redistributed pro rata across cancer deaths for all sites other than liver, pancreas, ovary, and lung (22).

- Digestive diseases: Residual category codes K72 and K76.9 were redistributed to the target causes $\mathrm{K} 70-\mathrm{K} 71$ and K73-K77; code K92.2 was redistributed to the target causes K27-K29, K70, and K74; code K92.0 was redistributed to target cause $\mathrm{K} 25$; and code K92.1 was redistributed to target cause K26, in varying proportion by sex and age, as proposed by the application of the GBD study methods used in Brazil's data from 1998 (23).

- Respiratory diseases: Residual category codes J96.9 and J98, identified in the GBD study in Brazil in 1998 (23), were redistributed proportionately to codes J00-J96.1 by age and sex, based on expert judgment.

- Injuries: Two studies in Brazil $(24,25)$ found that about $6 \%$ of defined causes of death detected after investigation of registered ill-defined conditions were identified as being due to injuries. This proportion was applied to correct for undercount of injury deaths in men, and the observed male-to-female mortality ratio (M:F MR) for injuries was used to correct for undercount in females. Injuries of undetermined intent were redistributed pro rata by age and sex to the GBD categories for intentional and unintentional injury.

\footnotetext{
4 World Health Organization International Classification of Diseases, Tenth Revision (http://www who.int/whosis/icd10).
} 
- Ill-defined causes: Following the adjustments described above, deaths assigned to general ill-defined codes (ICD-10 codes R00-R99) were redistributed proportionately by age and sex to other causes, apart from injuries.

\section{Estimating cause-specific mortality rates}

The resultant cause-specific proportions were then applied to the mortality envelope to calculate the average annual number of deaths by cause, age, and sex in the Northeast region of Brazil for 2002-2004. Then, age-standardized mortality rates by cause, with and without the corrections described above, were computed for the Northeast region. For subnational comparative analysis, similar rates were derived for the South region, after adjusting the VR data using the same methods described above. In this case, the adjustments to the causeof-death data were much less extensive.

To control for the effect of variable age distributions among regions, directly standardized mortality rates by cause of death and by sex were calculated using the age distribution of the Brazilian population in the 2000 census as the standard. Mortality rates from the South region were used as the reference rates.

\section{RESULTS}

The average annual distribution of selected characteristics for the Northeast and South regions of Brazil for 2002-2004 is shown in Table 1. The risk of child death in the Northeast region is estimated to be more than twice that in the South region for both sexes. A high proportion of unregistered deaths in the Northeast region leads to overestimation of life expectancy when using uncorrected VR data. The high proportion of ill-defined causes as well as misclassification of registered deaths to nonspecific categories of cardiovascular diseases, cancers, injuries, and digestive and respiratory tract diseases are major policy concerns in the Northeast region versus the South region.

The relative importance of the leading causes of mortality in terms of the number of deaths at all ages in the VR data for the same period, with and without correction for undercount and misdiagnosis, can be seen in Table 2. For males,

TABLE 1. Average annual distribution of selected characteristics for the Northeast and South regions of Brazil, 2002-2004

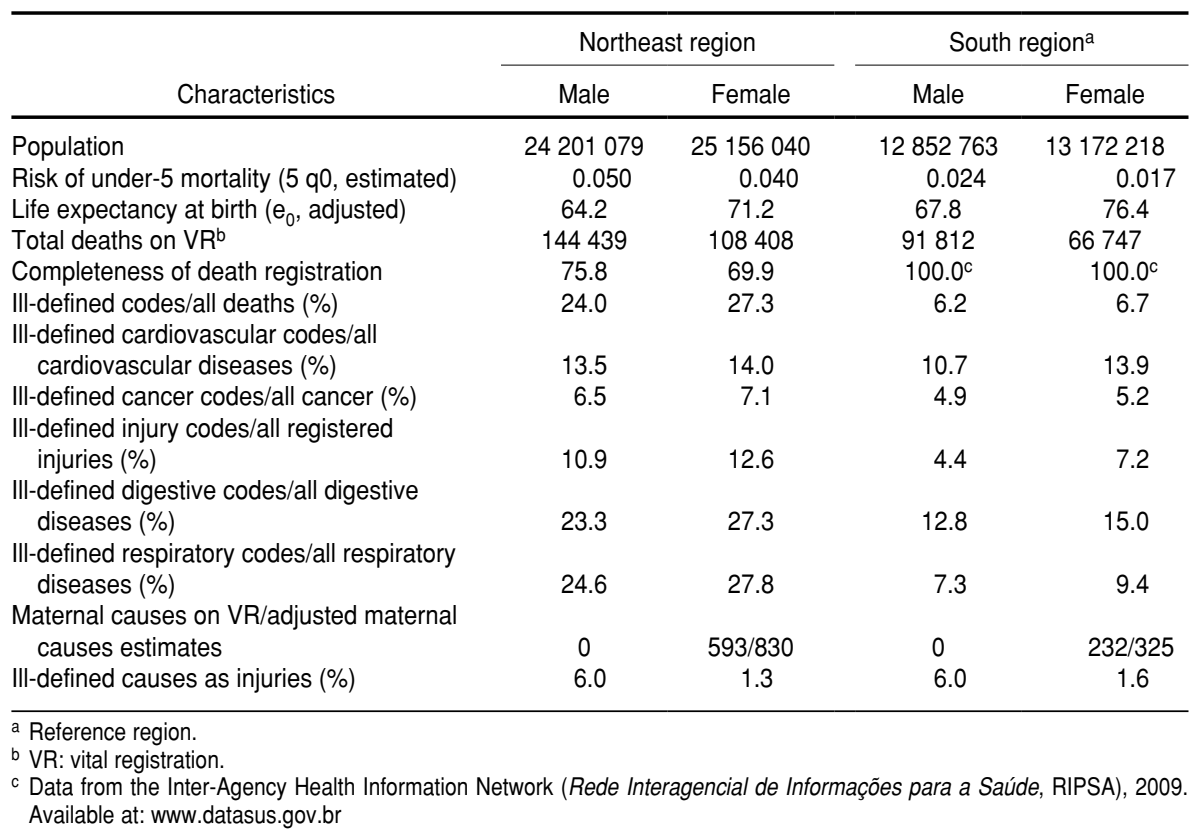

homicide ranked first in the original VR data but third in the adjusted data. After adjustment, cerebrovascular disease and ischemic heart disease (IHD) were estimated to have caused $20 \%$ of all deaths in men and $23 \%$ of deaths in women during the 2002-2004 period. In general, the adjustments had little impact on the rank order based on proportional mortality for the majority of the 20 leading causes of death, with the exception of ill-defined diseases, which ranked first in the observed VR data.

The importance of adjusting the data was illustrated by the substantial changes in the magnitude of risks of mortality from these causes, as shown in Figures 1a and 1b, which compare the original and adjusted average annual age-standardized mortality rates for the Northeast region. Adjusted death rates in males doubled for IHD, lower respiratory infections, chronic obstructive pulmonary disease (COPD), perinatal conditions, prostate cancer, and cirrhosis. For females, rates of IHD, lower respiratory infections, COPD, road traffic accidents, diarrheal diseases, congenital anomalies, protein-energy malnutrition, stomach cancer, and maternal conditions were also more than $100 \%$ higher than suggested by the original data (Figures $1 \mathrm{a}$ and $1 \mathrm{~b}$ ). Table 3 shows average annual age-standardized mortality rates in the Northeast region compared to the South region for the same three-year period. The rates for males are higher in the Northeast region versus the South region for almost all diseases except IHD, COPD, lung cancer, stomach cancer, and prostate cancer. Females in the Northeast region were also estimated to have higher death rates from almost all causes, apart from COPD, lung cancer, and breast cancer. Rate-ratios were two or more times higher in the Northeast region for diarrheal diseases, proteinenergy malnutrition, and perinatal conditions, for both males and females, and for maternal conditions in females.

\section{DISCUSSION}

The findings of this study emphasize the importance of correcting VR data for under-registration and misclassification of causes of death in the Northeast region. Corrected cause-specific mortality rates are higher in this region than in the South region for the majority of causes of death, including several noncommunicable conditions. Corrections substantially increase the inequality in death rates for almost all causes across these two regions, with concomitant changes in the rank order of some important causes of death.

Although mortality rates from cardiovascular diseases, particularly cere- 
TABLE 2. Observed and corrected ${ }^{a}$ cause-specific proportional mortality based on vital registration (VR) data, Northeast region, Brazil, 2002-2004

\begin{tabular}{|c|c|c|c|c|c|}
\hline Rank & Cause of death & $\begin{array}{l}\text { Observed } \\
\text { VR data } \\
(\%)\end{array}$ & Rank & Cause of death & $\begin{array}{c}\text { Corrected } \\
\text { VR data } \\
(\%)\end{array}$ \\
\hline Males & & & Males & & \\
\hline 1 & III-defined diseases & 24.0 & 1 & Cerebrovascular disease & 10.1 \\
\hline 2 & Homicide & 7.4 & 2 & Ischemic heart disease & 9.9 \\
\hline 3 & Cerebrovascular disease & 7.1 & 3 & Homicide & 8.5 \\
\hline 4 & Ischemic heart disease & 5.8 & 4 & Perinatal conditions & 7.2 \\
\hline 5 & Perinatal conditions & 4.7 & 5 & Road traffic accidents & 5.0 \\
\hline 6 & Road traffic accidents & 4.3 & 6 & Diabetes mellitus & 4.0 \\
\hline 7 & Diabetes mellitus & 2.9 & 7 & Lower respiratory infectious & 3.8 \\
\hline 8 & Hypertensive heart disease & 2.3 & 8 & Cirrhosis & 3.4 \\
\hline 9 & Lower respiratory infectious & 2.0 & 9 & Hypertensive heart disease & 3.3 \\
\hline 10 & Cirrhosis & 1.9 & 10 & $\mathrm{COPD}^{\mathrm{b}}$ & 3.1 \\
\hline 11 & III-defined injuries & 1.9 & 11 & Prostate cancer & 2.0 \\
\hline 12 & COPD & 1.6 & 12 & Diarrheal diseases & 1.6 \\
\hline 13 & Prostate cancer & 1.3 & 13 & Congenital anomalies & 1.4 \\
\hline 14 & Drowning & 1.2 & 14 & Drowning & 1.4 \\
\hline 15 & Diarrheal diseases & 1.1 & 15 & Protein-energy malnutrition & 1.4 \\
\hline 16 & Inflammatory heart diseases & 1.0 & 16 & Inflammatory heart diseases & 1.3 \\
\hline 17 & Lung cancer & 1.0 & 17 & Lung cancer & 1.3 \\
\hline 18 & Congenital anomalies & 0.9 & 18 & Nephritis and nephorosis & 1.3 \\
\hline 19 & Nephritis and nephorosis & 0.9 & 19 & Stomach cancer & 1.3 \\
\hline 20 & Protein-energy malnutrition & 0.9 & 20 & Tuberculosis & 1.0 \\
\hline \multicolumn{2}{|c|}{ Females } & & \multicolumn{2}{|c|}{ Females } & \\
\hline 1 & III-defined diseases & 27.3 & 1 & Cerebrovascular disease & 13.1 \\
\hline 2 & Cerebrovascular disease & 9.5 & 2 & Ischemic heart disease & 9.8 \\
\hline 3 & Ischemic heart disease & 6.0 & 3 & Diabetes mellitus & 7.5 \\
\hline 4 & Diabetes mellitus & 5.5 & 4 & Perinatal conditions & 6.2 \\
\hline 5 & Perinatal conditions & 4.5 & 5 & Hypertensive heart disease & 4.9 \\
\hline 6 & Hypertensive heart disease & 3.5 & 6 & Lower respiratory infectious & 4.8 \\
\hline 7 & Lower respiratory infectious & 2.4 & 7 & COPD & 3.1 \\
\hline 8 & COPD & 1.5 & 8 & Breast cancer & 1.9 \\
\hline 9 & Breast cancer & 1.4 & 9 & Diarrheal diseases & 1.8 \\
\hline 10 & Diarrheal diseases & 1.2 & 10 & Congenital anomalies & 1.7 \\
\hline 11 & Road traffic accidents & 1.2 & 11 & Road traffic accidents & 1.7 \\
\hline 12 & Congenital anomalies & 1.1 & 12 & Protein-energy malnutrition & 1.5 \\
\hline 13 & Protein-energy malnutrition & 1.0 & 13 & Cervix uteri cancer & 1.4 \\
\hline 14 & Cervix uteri cancer & 1.0 & 14 & Inflammatory heart diseases & 1.3 \\
\hline 15 & Inflammatory heart diseases & 1.0 & 15 & Cirrhosis & 1.3 \\
\hline 16 & Nephritis and nephorosis & 0.9 & 16 & Nephritis and nephorosis & 1.2 \\
\hline 17 & Lung cancer & 0.8 & 17 & Lung cancer & 1.0 \\
\hline 18 & Homicide & 0.7 & 18 & Homicide & 1.0 \\
\hline 19 & Stomach cancer & 0.6 & 19 & Stomach cancer & 0.9 \\
\hline 20 & Liver cancer & 0.6 & 20 & Maternal conditions & 0.9 \\
\hline
\end{tabular}

a Adjusted for undercount and misdiagnosis.

${ }^{b}$ Chronic obstructive pulmonary diseases.

brovascular diseases, have declined in the most developed regions of Brazil $(11,13,14)$, the current findings suggest that the Northeast region's population is at higher risk of dying from stroke, as from all other cardiovascular diseases except IHD, than the population in the wealthier South region. This confirms the inverse association between cardiovascular diseases and social and economic factors found in an earlier study diabetes among this population versus the South region's population is likely to have important implications for health planning in the country.

The leading cause of injury deaths among men in the Northeast region was homicide, followed by road traffic accidents and drowning. The risk of dying from homicide was 30\% higher in this region compared with the South region, based on observed VR data (not shown), but this increased to $90 \%$ after applying correction procedures. After increasing steadily from 1980 to 2002, a reduction in firearm-related homicide in Brazil occurred after gun control legislation was enacted in 2004 (28). Homicide and road traffic accidents are a much greater cause of death among males than females. Although mortality rates from traffic accidents based on crude death registration data were higher in the South region versus the Northeast region (data not shown), the correction methods that were applied suggest that they were relatively similar. Alcohol, excess speed, and poor conservation of roads and highways, as well as a high number of motorcyclists, are important determinants of the high death rate from traffic accidents in Brazil $(29,30)$.

This study confirmed the likelihood of injuries being miscoded to ill-defined diseases, as detected in previous research $(24,25)$. Furthermore, recent evidence from Brazil indicates that $14 \%$ of recorded ill-defined conditions and unrecorded deaths investigated with verbal autopsy in some cities of Minas Gerais State (Southeast region) were injuries that were not recorded in the VR data (31). Hence, this study's redistribution of a proportion of ill-defined deaths to injuries is innovative, as the original GBD study assumed that injuries were well documented and thus proposed redistribution of ill-defined causes only for natural causes (19).

Prostate, lung, and stomach cancer were the most common types of cancer deaths among men in the Northeast region. For women, four types of cancer were ranked among the 20 top causes of death: breast cancer, cervix uteri cancer, lung cancer, and stomach cancer. Using the rates in the South region as a reference, an excess mortality risk in the Northeast region occurred only for cervical cancer. Cervical cancer is one of the most treatable cancers if diagnosed at an early stage and treated effectively. 
FIGURE 1a. Crude and adjusted age-standardized average annual mortality rates for males for 20 leading causes of death, Northeast region, Brazil, 2002-2004

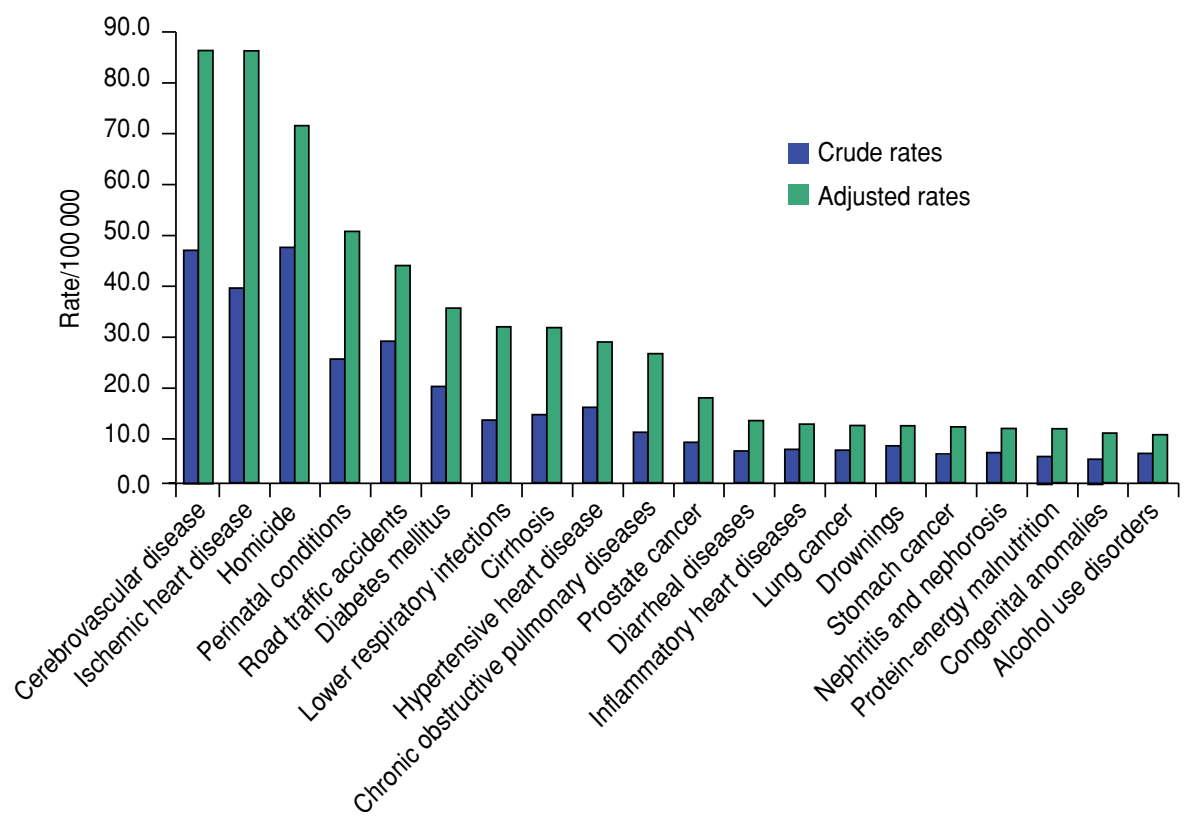

FIGURE 1b. Crude and adjusted age-standardized average annual mortality rates for females for 20 leading causes of death, Northeast region, Brazil, 2002-2004

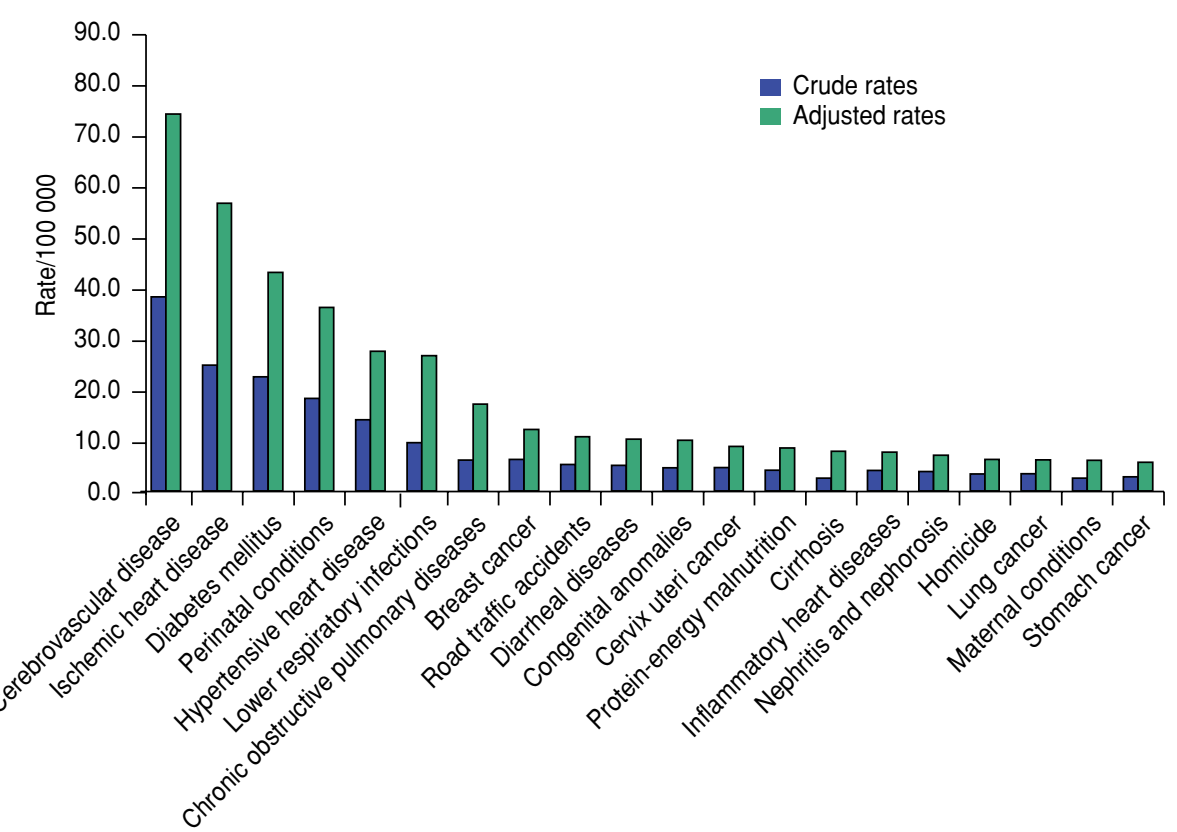

As uptake of preventive tests in Brazilian women is associated with access to medical care (32), the higher occurrence of cervical cancer in the Northeast is probably due to poor access to early diagnostic measures such as Pap smear screening (16). Higher mortality rates from breast cancer in the South region may be explained by a higher prevalence of various risk factors such lower fertility rates, which have been reported to be as- sociated with incidence in the Americas (33). Higher risks of death from lung cancer among men and women in the South region are likely to be the result of higher tobacco use (34). In the case of prostate cancer, mortality rates are relatively similar in the two regions even though prognostic measures such as digital rectal examinations and prostatespecific antigen (PSA) level tests, which are associated with better survival rates
(35), are likely to be less widely available in the Northeast region.

Patterns of mortality from lower respiratory infections, nephritis and nephorosis, and alcohol use disorders obtained from the observed data indicated lower death rates in the Northeast region versus the South region (data not shown). Corrected data for these conditions were strikingly different, however, showing higher mortality risks in the Northeast 


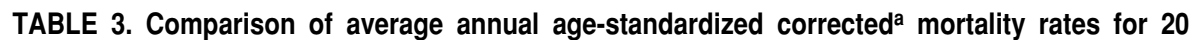
leading causes of death, Northeast and South regions, Brazil, 2002-2004

\begin{tabular}{|c|c|c|c|}
\hline & $\begin{array}{l}\text { Northeast region } \\
\text { (a) }\end{array}$ & $\begin{array}{l}\text { South region } \\
\text { (b) }\end{array}$ & $\begin{array}{c}\text { Rate-ratio } \\
\text { (a/b) }\end{array}$ \\
\hline \multicolumn{4}{|l|}{ Male } \\
\hline Cerebrovascular disease & 85.1 & 75.9 & 1.1 \\
\hline Ischemic heart disease & 84.8 & 96.3 & 0.9 \\
\hline Homicide & 70.1 & 37.9 & 1.9 \\
\hline Perinatal conditions & 49.3 & 17.1 & 2.9 \\
\hline Road traffic accidents & 42.6 & 43.8 & 1.0 \\
\hline Diabetes mellitus & 34.3 & 23.0 & 1.5 \\
\hline Lower respiratory infectious & 30.6 & 23.8 & 1.3 \\
\hline Cirrhosis & 30.4 & 23.2 & 1.3 \\
\hline Hypertensive heart disease & 27.6 & 16.4 & 1.7 \\
\hline $\mathrm{COPD}^{\mathrm{C}}$ & 25.3 & 60.2 & 0.4 \\
\hline Prostate cancer & 16.6 & 17.9 & 0.9 \\
\hline Diarrheal diseases & 12.1 & 2.0 & 6.1 \\
\hline Inflammatory heart diseases & 11.5 & 9.5 & 1.2 \\
\hline Lung cancer & 11.2 & 26.1 & 0.4 \\
\hline Drowning & 11.1 & 6.8 & 1.6 \\
\hline Stomach cancer & 10.9 & 14.7 & 0.7 \\
\hline Nephritis and nephorosis & 10.6 & 8.3 & 1.3 \\
\hline Protein-energy malnutrition & 10.5 & 3.6 & 2.9 \\
\hline Congenital anomalies & 9.7 & 7.4 & 1.3 \\
\hline Alcohol use disorders & 9.4 & 6.4 & 1.5 \\
\hline \multicolumn{4}{|l|}{ Female } \\
\hline Cerebrovascular disease & 73.8 & 57.0 & 1.3 \\
\hline Ischemic heart disease & 56.3 & 56.9 & 1.0 \\
\hline Diabetes mellitus & 42.8 & 25.0 & 1.7 \\
\hline Perinatal conditions & 35.9 & 13.4 & 2.7 \\
\hline Hypertensive heart disease & 27.3 & 15.1 & 1.8 \\
\hline Lower respiratory infectious & 26.5 & 17.9 & 1.5 \\
\hline COPD & 17.0 & 27.2 & 0.6 \\
\hline Breast cancer & 12.0 & 13.5 & 0.9 \\
\hline Road traffic accidents & 10.6 & 10.1 & 1.0 \\
\hline Diarrheal diseases & 10.1 & 1.9 & 5.3 \\
\hline Congenital anomalies & 9.9 & 6.6 & 1.5 \\
\hline Cervix uteri cancer & 8.7 & 5.4 & 1.6 \\
\hline Protein-energy malnutrition & 8.4 & 2.7 & 3.1 \\
\hline Cirrhosis & 7.7 & 4.9 & 1.6 \\
\hline Inflammatory heart diseases & 7.5 & 5.6 & 1.3 \\
\hline Nephritis and nephorosis & 6.9 & 5.8 & 1.2 \\
\hline Homicide & 6.1 & 4.0 & 1.5 \\
\hline Lung cancer & 6.0 & 8.8 & 0.7 \\
\hline Maternal conditions & 6.0 & 2.5 & 2.4 \\
\hline Stomach cancer & 5.6 & 5.6 & 1.0 \\
\hline
\end{tabular}

a Adjusted for undercount and misdiagnosis.

b Rates per 100000 population are age-adjusted to the 2000 Brazilian Census population by five-year age groups.

c Chronic obstructive pulmonary diseases.

region. COPD was higher in the South region in both the observed and corrected VR data. This finding is not surprising considering the South region's higher prevalence of smoking (34), which is estimated to be responsible for at least $75 \%$ of COPD deaths (36).

Perinatal conditions, diarrheal diseases, protein-energy malnutrition, and congenital anomalies, although more frequent among children under 5 years old, ranked among the leading causes of mortality at all ages in the Northeast region. Risks for death due to the former three causes and maternal conditions for females were at least two times higher in the Northeast region versus the South region. This implies a much higher number of deaths in the Northeast region, a situation that could be avoided through public health interventions such as those designed to increase accessibility to health care. One positive note is the finding that prevalence of child malnutrition in the Northeast region fell by almost threequarters between 1996 and 2006 due to increasing purchasing power among the poorest families, and improvements in maternal schooling (37).

Since 2005 the Brazilian government has implemented initiatives that target a reduction in ill-defined causes of death in both the North and Northeast regions (38). In 2008, ill-defined conditions still accounted for $7.9 \%$ of all deaths in the Northeast region (data available from www.datasus.gov.br). Thus, the impact of improvements in cause-specific mortality data must be considered when interpreting trend analyses, especially given ongoing efforts to improve the quality of recorded causes of death in Brazil.

Given the importance of maximizing the public health utility of cause-ofdeath data, new correction approaches have been developed, essentially based on a review of the typologies of residual category codes, leading to improved methods for assigning such deaths to a set of underlying causes (39). This study was consistent with these efforts and the conceptual approach developed in the GBD study (19) and had the added advantage of access to local evidence, which was incorporated into the redistribution process as described by Akgün et al. (40). This use of local data enhances the comparability of the study's results on risks of death from leading causes at the subnational level in Brazil.

This study had some limitations stemming from the procedures used to ascertain accurate mortality rates. First, in accordance with the methodology used to redistribute ill-defined cardiovascular codes, a fraction of the deaths corresponding to those codes were reassigned to IHD. However, the procedure used to determine that fraction could have overestimated it (21). Nonetheless, after correction, the findings on stroke and IHD mortality differentials between the Northeast region and the South region are consistent with other international data that indicate stroke is more important in middle-income countries and IHD is of greater magnitude in high-income countries (41). The second limitation is the possibility that the GBD methods used to correct cancer mortality rates may have overestimated the cancer mortality risks, based on local evidence that cancer is recorded more accurately in registration data, and is much less likely to be classified to ill-defined categories, compared with other natural causes $(15,24)$.

In conclusion, the current findings suggest the use of caution when interpreting observed VR data from Brazil's Northeast region or any data from countries at a similar level of development. Without adjustment, observations about 
the health situation are likely to be misleading, and socioeconomic inequalities hidden. Despite some unavoidable uncertainty in the processes of correction and estimation used in mortality analysis, all cause-specific mortality rates in poor populations should be adjusted for undercount and misdiagnoses in order to more reliably describe disease patterns.

Acknowledgments. EF and DMXA were sponsored by Brazil's Office of Coordination for the Improvement of Higher Education Personnel (Coordenação de Aperfeiçoamento de Pessoal de Nível
Superior, CAPES) for research conducted at the University of Queensland, Australia, from September 2006 to February 2007. EF is a fellow of Brazil's National Council for Scientific and Technological Development (Conselho Nacional de Desenvolvimento Científico e Tecnológico, CNPq).

\section{REFERENCES}

1. Mathers CD, Fat DM, Inoue M, Rao C, Lopez AD. Counting the dead and what they died from: an assessment of the global status of cause of death data. Bull World Health Organ. 2005;83(3):171-80.

2. AbouZahr C, Boerma T. Health information systems: the foundations of public health. Bull World Health Organ. 2005;83(8):578-83.

3. The PLoS Medicine Editors. Can we count on global health estimates? PLoS Med. 2010;7(11):e1001-2.

4. Pan American Health Organization. Health situation in the Americas: basic health indicators 2010. Washington: PAHO; 2010.

5. Lopez AD. Who dies of what? A comparative analysis of mortality conditions in developed countries around 1987. World Health Stat Q. 1990;43(2):105-14.

6. National Commission on Social Determinants of Health (BR). The social causes of health inequities in Brazil. Rio de Janeiro: Editora Fiocruz; 2008.

7. Banco Central do Brasil. Evolução do IDH das grandes regiões e unidades da federação. B Reg BCB. 2009;3(1):91-4. Available from: http:/ / www.bcb.gov.br/pec/boletimre gional/port/2009/01/br200901b1p.pdf

8. Instituto Brasileiro de Geografia e Estatística (BR). Síntese de indicadores sociais, 2005. Rio de Janeiro: IBGE; 2006.

9. Andrade CLT, Szwarcwald CL. Desigualdades sócio-espaciais da adequação das informações de nascimentos e óbitos do Ministério da Saúde, Brasil, 2000-2002. Cad Saude Publica. 2007;23(5):1207-16.

10. França E, Abreu DMX, Rao C, Lopez AD. Evaluation of cause-of-death statistics for Brazil, 2002-2004. Int J Epidemiol. 2008;37(4):891901.

11. André C, Curioni CC, Cunha CB, Veras R. Progressive decline in stroke mortality in Brazil from 1980 to 1982, 1990 to 1992, and 2000 to 2002. Stroke. 2006;37(11):2784-9.

12. Oliveira GMM, Klein $\mathrm{CH}$, Souza e Silva NA. Mortalidade por doenças cardiovasculares em três estados do Brasil de 1980 a 2002. Rev Panam Salud Publica. 2006;19(2):85-93.

13. Curioni $C$, Cunha $C B$, Veras RP, André $C$. The decline in mortality from circulatory diseases in Brazil. Rev Panam Salud Publica. 2009;25(1):9-15.

14. Malta DC, Moura L, Souza FM, Rocha FM, Fernandes FM. Doenças crônicas não-transmissíveis: mortalidade e fatores de risco no Brasil, 1990 a 2006. In: Ministério da Saúde (BR). Saúde Brasil 2008: 20 anos do Sistema Ùnico de Saúde no Brasil. Brasília: MS; 2009. Pp. 337-63.
15. Gamarra CJ, Valente JG, Silva GA. Correction for reported cervical cancer mortality data in Brazil, 1996-2005. Rev Saude Publica. 2010;44(4):629-38.

16. Schmidt MI, Duncan BB, Silva GA, Menezes AM, Monteiro CA, Barreto SM, et al. Chronic non-communicable diseases in Brazil: burden and current challenges. Lancet. 2011;377(9781):1949-61.

17. Murray CJL, Ferguson BD, Lopez AD, Guillot M, Salomon JA, Ahmad O. Modified logit life table system: principles, empirical validation, and application. Pop Stud. 2003;57(2): 165-82.

18. Cavalini LT, Ponce de Leon ACM. Correção de sub-registros de óbitos e proporção de internações por causas maldefinidas. Rev Saude Publica. 2007;41(1):85-93.

19. Murray CJL, Lopez AD. Estimating causes of death: new methods and global and regional applications for 1990. In: Murray CJL, Lopez $\mathrm{AD}$, editors. The global burden of disease: a comprehensive assessment of mortality and disability from diseases, injuries, and risk factors in 1990 and projected to 2020. Cambridge, MA: Harvard University Press; 1996. Pp. 118-200.

20. Laurenti R, Jorge MHP M, Gotlieb SLD. A mortalidade materna nas capitais brasileiras: algumas características e estimativa de um fator de ajuste. Rev Bras Epidemiol. 2004;7(4):449-60.

21. Lozano R, Murray CJL, Lopez AD, Satoh T. Miscoding and misclassification of ischaemic heart disease mortality. Evidence for Health Policy Working Paper No. 12. Geneva: WHO Global Programme; 2001.

22. Boschi-Pinto C, Murray CJL, Lopez AD, Lozano R. Cancer survival by site for 14 regions of the world. GPE Discussion Paper No. 13. Geneva: World Health Organization; 2000.

23. Gadelha AMJ, Leite IC, Valente JG, Schramm JMA, Portela MC, Campos MR. Relatório final do projeto estimativa da carga de doença do Brasil-1998. Rio de Janeiro: Fundação Oswaldo Cruz; 2002.

24. Mello-Jorge MHP, Gotlieb SLD, Laurenti R. O sistema de informações sobre mortalidade: problemas e propostas para o seu enfrentamento I-mortes por causas naturais. Rev Bras Epidemiol. 2002;5(2):197-211.

25. Teixeira CLS, Klein CH, Bloch KV, Coeli CM. Reclassificação dos grupos de causas prováveis dos óbitos de causa mal definida, com base nas autorizações de internação hospitalar no Sistema Único de Saúde, Estado do Rio de Janeiro, Brasil. Cad Saude Publica. 2006;22(6):1315-24.
26. Ishitani LH, Franco GC, Perpétuo IHO, França E. Desigualdade social e mortalidade precoce por doenças cardiovasculares no Brasil. Rev Saude Publica. 2006;40(4):684-91.

27. Fuchs SC, Moreira LB, Camey SA, Moreira MB, Fuchs FD. Clustering of risk factors for cardiovascular disease among women in Southern Brazil: a population-based study. Cad Saude Publica. 2008;24 Suppl 2:S85-93.

28. Duarte EC, Monteiro RA, Mascarenhas MDM, Silva MMA. As violências e os acidentes como problemas de saúde pública no Brasil: marcos das políticas públicas e a evolução da morbimortalidade durante os 20 anos do Sistema Ùnico de Saúde. In: Ministério da Saúde (BR). Saúde Brasil 2008: 20 anos do Sistema Ùnico de Saúde no Brasil. Brasília: MS; 2009. Pp. 312-36.

29. Souza ER, Lima MLC. The panorama of urban violence in Brazil and its capitals. Cienc Saude Coletiva. 2006;11(2):363-73.

30. Souza MFM, Malta DC, Conceição GMS, Silva MMA, Gazal-Carvalho C, Morais Neto OL. Análise descritiva e de tendência de acidentes de transporte terrestre para políticas sociais no Brasil. Epidemiol Serv Saude. 2007;16(1):33-44.

31. Campos D, França E, Loshi RH, Souza MFM. Uso da autópsia verbal na investigação de óbitos com causa mal definida em Minas Gerais, Brasil. Cad Saude Publica. 2010;26(6):1221-33.

32. Novaes HMD, Braga PE, Schout D. Fatores associados à realização de exames preventivos para câncer nas mulheres brasileiras, PNAD 2003. Cienc Saude Coletiva. 2006;11(4):102335.

33. Robles SC, Galanis E. Breast cancer in Latin America and the Caribbean. Rev Panam Salud Publica. 2002;11(3):178-85.

34. Wünsch Filho V, Mirra AP, López RVM, Antunes LF. Tabagismo e câncer no Brasil: evidências e perspectivas. Rev Bras Epidemiol. 2010;13(2):175-87.

35. Migowski A, Silva GA. Sobrevida e fatores prognósticos de pacientes com câncer de próstata clinicamente localizado. Rev Saude Publica. 2010;44(2):344-52.

36. Centers for Disease Control and Prevention (US). Annual smoking-attributable mortality, years of potential life lost, and productivity losses, United States, 1997-2001. MMWR Morb Mortal Wkly Rep. 2005;54(25):625-8.

37. Lima AL, Silva AC, Konno SC, Conde WL, Benicio MH, Monteiro CA. Causas do declínio acelerado da desnutrição infantil no Nordeste do Brasil (1986-1996-2006). Rev Saude Publica. 2010;44(1):17-27.

38. Ministério da Saúde (BR). Vigilância em saúde no SUS: fortalecendo a capacidade de res- 
posta para velhos e novos desafios. Brasília: MS; 2006. Pp. 43-7. Available from: http:// bvsms.saude.gov.br/bvs/publicacoes/vigi lancia_saude_SUS.pdf

39. Naghavi M, Makela S, Foreman K, O’Brien J, Pourmalek F, Lozano R. Algorithms for enhancing public health utility of national causes-of-death data. Popul Health Metr. 2010;8:9.
40. Akgün S, Rao C, Yardim N, Basara BB, Aydin $\mathrm{O}$, Mollahaliloglu S, et al. Estimating mortality and causes of death in Turkey: methods, results and policy implications. Eur J Public Health. 2007;17(6):593-9.

41. World Health Organization. The global burden of disease: 2004 update [Internet]. Geneva: WHO; 2008. Available from: http:// www.who.int/healthinfo/global_burden_ disease/2004_report_update/en/index.html Accessed 15 February 2011.

Manuscript received on 4 March 2011. Revised version accepted for publication on 5 October 2011 .

RESUMEN Objetivo. Presentar de qué manera el ajuste de los datos incompletos y de la clasificación errónea de las causas de muerte registradas en el sistema del registro civil puede ayudar a estimar los riesgos de mortalidad debida a las principales causas de muerte en el nordeste del Brasil.

\section{Comparación de las tasas de mortalidad bruta y ajustada debida a las principales causas de muerte en el nordeste del Brasil} Métodos. Después de calcular el número total de defunciones por edad y sexo en el nordeste del Brasil entre 2002 y 2004 mediante la corrección del subregistro de los datos del registro civil, se aplicaron algoritmos de ajuste a la estructura de las causas de defunción notificadas. Las tasas de mortalidad promedio anuales estandarizadas

por edades se calcularon según la causa, con y sin las correcciones, y se compararon con las tasas de mortalidad de la región meridional del Brasil después de efectuar un ajuste de los posibles diagnósticos erróneos.

Resultados. Las tasas de mortalidad debidas a cardiopatía isquémica, infecciones de las vías respiratorias inferiores, enfermedad pulmonar obstructiva crónica y enfermedades perinatales fueron más de $100 \%$ mayores para ambos sexos que las sugeridas por los datos habituales del registro civil. Las tasas de mortalidad corregidas por causa específica fueron mayores en la región del nordeste que en la región meridional para la mayoría de las causas de muerte, incluso para varias enfermedades no transmisibles.

Conclusiones. La falta de ajuste de los datos del registro civil para compensar el subregistro de los casos notificados y los diagnósticos erróneos ocasionará una subestimación del riesgo de mortalidad para las poblaciones de la región del nordeste, más vulnerables que las de otras regiones del país. Para comprender de manera más fiable el patrón de las enfermedades, en las poblaciones pobres deben ajustarse todas las tasas de mortalidad por causa específica.

Palabras clave Causas de muerte; mortalidad; estadísticas vitales; Brasil. 